\title{
THE MANIFESTATION OF PROSOCIAL AND AGGRESSIVE BEHAVIOR OF PRESCHOOL CHILDREN DEPENDING ON SEX AND AGE
}

Aid Bulićn

Original scientific paper

\section{Gabriel Pinkas}

Faculty of Philosophy, University of Tuzla, $B \& H$

Faculty of Philosophy, University of Tuzla, $B \& H$

Received: 26.06 .2016

Accepted: 27.08.2016

\begin{abstract}
In this paper we present the results of research on a sample of 101 children. All children attending kindergarten "Sunčica" that exists within the Public Institution for pre-school education "Our child" Tuzla. Our goal was to investigate and determine which behavior, prosocial or aggressive, is more manifested by pre-school children. Also, we wanted to determine whether there is a significant difference in the expression of aggressive and prosocial behavior of children in relation to their age and gender. The results we obtained showed that preschool children manifested more prosocial than aggressive behavior, that there are significant differences in the expression of prosocial and aggressive behavior of children in relation to sex, and that there are significant differences between certain age groups of children in the context of prosocial behavior while among some age groups in the context of prosocial behavior and among all age groups in context of aggressive behavior there were no statistically significant differences.
\end{abstract}

Key words: prosocial behavior, aggressive behavior, children, kindergarten.

\section{INTRODUCTION}

The first social environment in which the child resides is family. The first social experience acquired through the family through interaction and communication primarily with parents and other members of the family. When it starts attending kindergarten, a child is faced with new situations for which it needs social skills in order to successfully master them. "The social experiences gained from family in the preschool years are the basis of all future relationships" (Brajša-Žganec, 2003, p. 76). From the foregoing we can see that parents are the most important factors of children's social development in the preschool period, and that their relationship to children and others, will largely depend on the behavior of children in other social contexts. Prosocial or aggressive manifestations by preschool children are undoubtedly strong influenced by their parents.
In addition to that the unquestionable influence parents have on the appearance of prosociality and aggressiveness of preschoolers, the logical question that arises is: why is the prosocial and aggressive behavior of preschoolers interesting to us? The answer would be: because the expression or non-expression of the mentioned behaviors of children in the preschool period may represent one of the important factors that will determine the direction of development of children in the future.

Also, we are interested in the relationship between the aforementioned behaviors. Their definition in the following chapters will give us a clearer picture that these are behaviors that are on opposite sides of the same continuum. If this was indeed the case, also confirmed by different authors who more or less agree with the previous statement.

\section{${ }^{1}$ Correspodence to:}

Aid Bulić, Faculty of Philosophy, University of Tuzla

Dr. Tihomila Markovića br.1, Tuzla, B\&H

Phone: +38761410809

E-mail: aid.bulic@gmail.com 
So Rushton (1985) believes that there are two concepts that are negatively correlated, but not necessarily in a causal relationship (Rushton, 1985, see: VlahovicŠtetić, 1994). Eron and Huesmann (1984) talk about the unique feature whereby the prosocial and aggressive behavior are only its behavioral adverse manifestations. Lea Pulkinen points out that it mutually exclusive styles of behavior acquired in childhood (Pulkkinen, 1984, see: Vlahović-Štetić, 1994).

\section{Prosocial behavior}

There are different definitions of the term prosocial behavior, however, what can be seen now is that prosociality includes activities and actions aimed at the welfare of others, and to acquire popularity by others.

Prosocial behavior is behavior that is related to willing, intentional behavior, which has positive implications on others (Eisenberg and Miller, 1987). On the other hand, there are opinions that the prosocial behavior vision of moral conduct that includes socially desirable behavior, such as sharing with others, help and cooperation (Vasta, Haith and Miller, 2004). A similar interpretation of prosocial behavior can be found in works of other authors who believe that it is any social behavior that contributes to the well-being of another individual or group, regardless of the level and type of personal gain or victims, or with a small possibility of reciprocal material or social rewards. (Bryan and London, 1970; Staub, 1978, see Krnjajić, 2002). However, we consider important to note that prosocial behavior cannot be determined only by selfdenial and self-sacrifice, but also it represents a certain ego satisfaction.

Prosocial behavior of preschoolers can be recognized through behavior such as helping other children, lending toys to other children, keeping other people's toys, sharing sweets, empathy with other children who are punished etc. Expressing or not, prosocial behavior of preschool children, can determine the later course of life of a child. Highlighting and development of prosociality is a necessity because it entails many positive consequences such as schoo/academic success, establishing better social relationships, and preparing children to be competent and responsible members of society to effectively solve social problems, which is also one of the important tasks of social development and education in general.

Very often the question is "does prosocial behavior of children exist, or are small children able to empa- thize"? In this chapter we will give some essential features of prosocial behavior in childhood, as well as the results of some studies that have addressed this issue at an early age.

The manifestation of prosocial behavior begins very early in a child's life, from infancy. With increasing age, comes increase of frequency and complexity of prosocial behavior, so that such behavior can often be seen from elder than from younger children (Brajša, Zuzul and Keresteš, 1991).

However, in certain circumstances were observed age differences in prosocial behavior. Thus, for example, in one study, older children more readily than younger children shared earned money, but only after they had been told that sharing with others is considered good procedure, to participate in an experiment about sharing or experimenter observing them. Without this information, the older children were no more generous than younger children. Age differences are usually seen in experimental, but not in terms of natural observations (Vasta et al., 2004).

The development of prosocial behavior with (possible) hereditary factors should be emphasized and the impact of culture to which the child belongs. The development of prosocial behavior is associated with cognitive and moral development, especially the development of empathy. Empathy and prosocial behavior are indicators of child's competent behavior and socio-emotional functioning. Also, girls are more prosocial than boys (Eisenberg and Mussen, 1989).

Assessment of prosocial behavior at an early age can be very useful in assessing antisocial behavior in adulthood (Eron and Huessman, 1984).

About the occurrence of prosocial behavior in childhood Basic and associates (2001) talk too. These authors point out that prosocial behavior occurs in the preschool period, and that prosociality of children of this age occurs more frequent than aggression. However, the higher count of prosocial behavior does not mean that they are sufficiently developed and that are used sufficiently. The results showed that certain prosocial behaviors occur rarely or never, which requires special work with the children.

\section{Aggressive behavior}

The complete opposite with respect to the aforementioned term prosocial behavior is aggressive behavior. Aggressiveness primarily refers to unacceptable forms of behavior, and not the interpretation of aggression as a constructive behavior. 
By various authors who have dealt with this complex phenomenon, we find various definitions of aggression. According Krnjajić (2002) under the construct of aggression he includes all activities, thoughts and impulses that lead to physical or psychological damage done to one or group of people. Zuzul believes that aggression is more or less pronounced, relatively stable tendency of an individual to the specific (provoking) situations, respond by attacking, threatening or seeking conflict or struggle in the broadest sense of the word (Zuzul, 1986- see at: Basic, Koller-Trbović and Weevil, 2005).

Following are definitions of aggressive behavior that in its constituent emphasize "intent" as an essential element in determining the aggressiveness. Aggressive behavior includes a wide range of specific behaviors that have the common feature of possible harm or injury to other people or things, and the intention to cause damage (Bouillet and Uzelac, 2007). Similarly is the definition of aggression as any behavior that causes harm or destroys property, with key emphasis on the intention of the presentation of such behavior (Vasta, Haith and Miller, 2004).

Aggressive behavior can be seen by preschool children and is usually manifested through arguments and shouting with other children, grabbing toys from other children, destroying toys, mockery, provoking etc. Therefore, we believe that it is important to examine expression of this behavior of preschoolers in order to promptly eliminate the negative consequences that such behavior entails. In doing so, we should bear in mind the fact that (none) expression aggression of preschoolers is often an indicator of later positive or negative direction of the development of children and youth.

Aggressive behavior represents entirely opposite to prosociality. Aggression is an important, indispensable and integral part of the development of every child, regardless of what age it is. Since the focus of our interest is the preschool period, it is important to point out that the phenomenon of aggression in this period, either at school or family, is not something that is new. What constitutes a stimulating factor of aggressiveness of preschoolers is children's exposure to aggressive scenes on television, movies, and video games.

Analysis of the definition of aggression as a different spectrum of behavior that is common ground that can cause harm to other people or things, and that there is an intention to commit harm, authors point out the existence of certain facts. So Krnjajić (2002) believes that children in all cultures and societies tend to display certain forms of aggressive behavior. Every society deals with the problem of aggressive behavior with respect to its own system of values and the process of socialization. Essau (2003) points out that aggression is a big burden for the company, both in material and in social terms. For such children the engagement of different system of psychosocial care and protection, juvenile courts and even special educational procedures are needed (ESSA, 2003).

It is important to note that the aggressiveness of children is a "normal" phenomenon, but within a certain period of development, and in a certain form. Thus, in a survey conducted by Holmberg (1977) he found that half of social interactions among children aged 12-18 months can be considered a conflict, or inherently violent disruptions (Holmberg, 1977, see at, Essau and Conradt, 2009).

In those early interpersonal conflicts young children learn and develop effective social strategies with which to fight for their rights and resolve social conflicts. In this way, they learn lessons that will help them in later activities in wider social environment. A certain amount of aggressiveness, not only to facilitate the development of these skills, but encourages aberrant behavior while playing leads to more successful mastering demands of everyday life (ESSA and Conradt, 2009).

A large part of their time pre-school children, in addition to the family, they spend in kindergarten. It is for them a new and unfamiliar environment where they have to fight for their position and status. In this struggle they will encounter many conflict situations that will need to resolve. Speaking of aggressiveness in kindergarten, Haug-Schnabel (1997) points out that a kindergarten or any other surrounding is not immune to the emergence of conflicts. She believes that it is quite normal. Only in such a situation it can learn that conflicts and their mastering are integral parts of human life, that pose no disaster, but that the common life is possible after the curses, insults and "licking the wounds" when you pass some time and when there mediate sympathetic people. This means that it meet compromise as a magical tool, but also an experience that is not so bad sometimes to give in and give up something, even though it initially seemed like a humiliation. From the above it becomes clear that a child in kindergarten, in the fight for its status as the realization that in addition to aggression it can use other ways to respond, depending on the situation and experience within the disposal. 
Bastašić (1990) points out that the kindergarten can do a lot on the channeling of aggression in games where physical activity dominates and where are nurtured movement and cooperation present. In this way, we turn aggression into something constructive, and co-operation as a component allows us encourage prosocial behavior. Pursuant to the above mentioned we can say that a certain amount and form of aggression are quite "normal" and even desirable in a child's behavior. It allows easier adoption of social skills, but here we primarily refer to the type of controlled aggressiveness in terms of highlighting their "me" and fight for their interests and needs. Over time, this form of aggression in the so-called socialized acceptable aggression, i.e., one that in addition to highlighting their own interests, respects the interests and needs of both sides. Although it might be more appropriate to the kind of aggression and call assertiveness.

Aggressiveness is a developmental phenomenon that occurs in all children regardless of the culture they come from. Since aggression involves intentional actions, and young children are not in the possibility that someone deliberately harm, then theoretically they cannot manifest aggression. But between the second and seventh month of life they are beginning to emerge reactions of anger, but most often these attacks of rage causes physical discomfort, the desire for attention, relieving itself, eating or going to bed (ESSA and Conradt, 2009).

In the second and third year appear tantrums and aggression against adults and peers. Same-sex dyads easily come into conflict than couples made up of boys and girls (Petermann \& Petermann, 2010). Instrumental aggression begins to emerge from 12 months and is in the form of deprivation of toys of other children.

Aggressiveness as a personality trait stabilizes very early, between the third and fourth year of life. Since learning cannot be finished so early, stability of aggressiveness is determined mainly by genetic factors. However, genetic factors make predispositions to certain traits, and learning depends on how these predispositions affect the development of personality traits. Social learning (learning by model), adopted by the aggressive behavior scheme, which is usually manifested in a certain situation where it learns to perform violent reaction. Also, they adopt norms and rules of conduct on the basis of which an evaluation of aggressive reaction is made, based on social learning and developing mechanisms of inhibition of aggression. Parents are a model for the development of aggressive behavior of children, or other family members i.e. the whole family interaction is a model of development of aggressive behavior. Also watching aggressive content through cartoons will contribute to the development of aggressive children (Bryce Žganec, 2003).

Directed expression of aggression, such as revenge, is a more frequent phenomenon in the behavior of children up to the fourth or fifth year of life. In this period about third outbreaks obtain this form. Verbal aggression gets more common, such as giving derogatory names, arguing and refusing to do something. Aggressive episodes are usually short-term, arguing preschoolers usually last less than half a minute (Wenara, 2003).

\section{RESEARCH METHODOLOGY}

\section{The aim of the research}

The aim of this paper is to investigate which behavior is more manifested by preschoolers, prosocial or aggressive, and determine whether there were differences in the expression of those behaviors in terms of gender and age preschoolers.

\section{Research tasks}

Investigate and determine which behavior is more manifested by preschoolers (prosocial and aggressive).

Examine whether there is a statistically significant difference in the manifestation of prosocial and aggressive behavior of preschoolers in terms of gender. Examine whether there is a statistically significant difference in the manifestation of prosocial and aggressive behavior of preschoolers with respect to age.

\section{Hypothesis}

We assume that preschoolers manifest more prosocial than aggressive behavior, and that there are significant differences in the manifestation of these behaviors in terms of gender and age of preschoolers. 


\section{Sub-hypotheses}

We assume that preschoolers manifest more prosocial than aggressive behavior.

We assume that there is a statistically significant difference in the manifestation of prosocial and aggressive behavior in terms of gender of preschoolers, and that boys manifest more aggressive, while girls manifest more prosocial behavior.

We assume that there is a statistically significant difference in the manifestation of prosocial and aggressive behavior in terms of age of preschoolers.

\section{The methods and procedures of research}

In this study, we used the following research methods: the method of theoretical analysis, survey methods.

Theoretical analysis is used for more precise understanding of the problem that is being investigated. It is accomplished through the use of logical methods: deduction, analysis, synthesis and scientific explanation. This method has the theoretical-cognitive and practical function. The first relates to the discovery of scientific truth, the facts, the law, disclosure and setting a new hypothesis. The second consists in the application of theoretical research obtained truth and formulating positions in solving practical tasks, which is the ultimate goal of educational research. It is complemented with empirical methods such as survey methods will also be used in this research.

Survey method is an empirical experimental method, which is a basic feature of addressing subjects that give opinions or statements about themselves. Survey procedure is suitable for the study of attitudes, beliefs and behaviors of teachers, students and parents (Stojakovic, 2003).

\section{Research instrument}

The scale for assessing the aggressiveness and prosocial behavior of children is intended for testing prosocial and aggressive behavior of preschool children. From a large number of concrete everyday children's reactions there were selected 10 for aggressive and 10 for prosocial behavior. When choosing the reaction, the authors have opted for the most common and which are easily perceived in the kindergarten. Each reaction is formulated in a particle scale.

This way, a standard assessment scale with twenty parts and two subscales (even particles are related to aggressive and odd on prosocial behavior) are made.
The task of the assessor is that on a scale of 5 degrees to estimate the frequency of specified behavior of individual children.

The numbers on the scale are defined as follows:

It never behaves that way,

It rarely behaves that way,

It sometimes behaves that way,

It often behaves that way,

It almost always behaves that way.

The restrictions that are placed in front of all these measuring instruments (scale of assessment) are: 1 . The feature that is estimated to have a clear behavioral manifestation, and 2. the assessors must be able to frequently note this behavior. As the manifestations of aggressive behavior are clear and recognizable, and the same goes for prosocial behavior, the first condition is satisfied. With regard to the second condition, it seems justified as the most appropriate assessors to suggest the educators in kindergartens. The scales of assessments are always saturated with specific errors of assessors, where it is logical to assume that this error is smaller if the assessment is performed by educators than e.g. parents. Educators are enough experienced and objective assessors. However in this case it should be count on classic errors in assessing: adjusting the criteria group, the personal equation, halo-effect and the like.

Of course, this scale is intended for other evaluators also who meet the requirement of being able to often enough observe the behavior of the child.

On a scale Pros/Ag obtained by linear response summarizing two results: sum of even particles gives an estimate of aggressive behavior, while the answer to the sum of odd particles gives the result of the subscales prosocial behavior. The theoretical range for each subscale is 10 to 50 points.

The authors of the mentioned scale are Miomir Zuzul and Vesna Vlahovic-Štetić (Vlahovic-Štetić, 1994).

The scale meets all the measurement characteristics and reliability of the scale measuring Cronbach Alpha coefficients ranging from .924 to .929 for prosocial, and 0.943 to 0.945 for aggressive behavior.

\section{Population and survey sample}

The population in this study consisted of preschoolers from the Municipality of Tuzla. The study sample consisted of preschoolers who attend kindergarten "Sunčica" which is part of the Public Institution for pre-school education "Naše dijete" Tuzla. The sample in this study consisted of 101 preschooler. 


\section{Analysis and interpretation of results}

In order to respond to the set objective, and hence the tasks of this study, we used a particular statistical calculation. This way we get the answers to the proposed hypotheses.

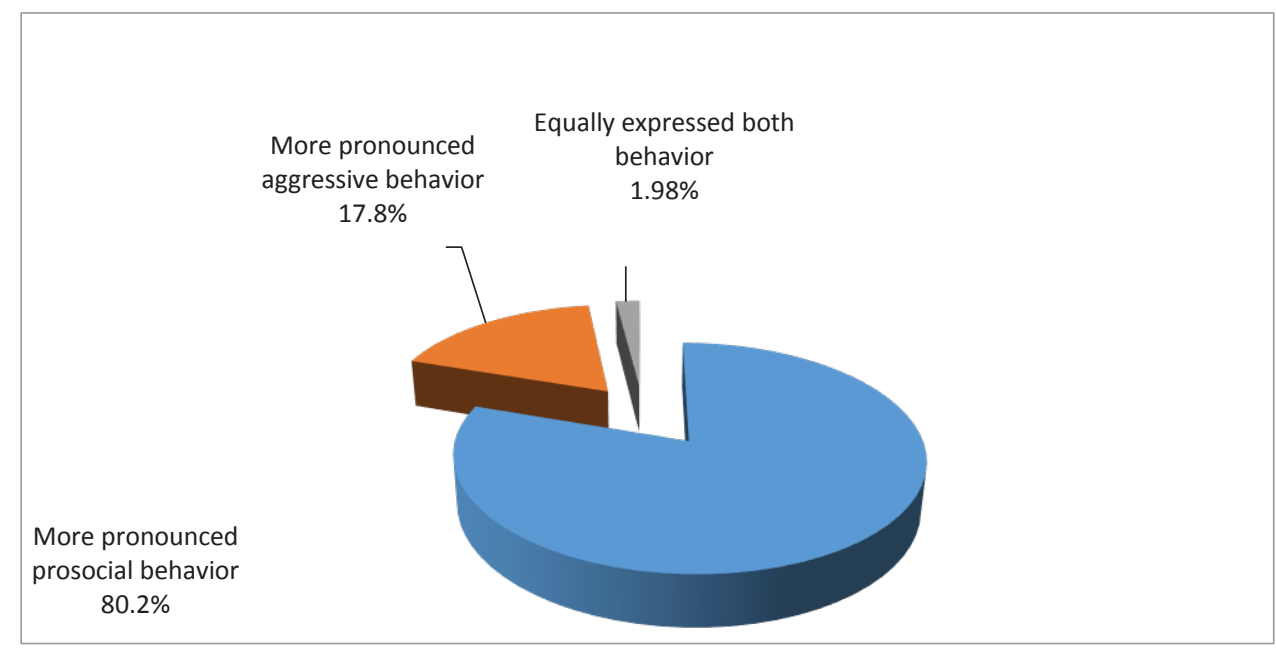

Figure 1: The expression of prosocial and aggressive behavior of preschoolers

Table 1. Descriptive statistics for prosocial and aggressive behavior in children

\begin{tabular}{cccccc}
\hline & $\mathrm{N}$ & Min. & Max. & $\mathrm{M}$ & SD \\
\hline Prosocial behavior & 101 & 18.00 & 50.00 & 34.8317 & 8.08216 \\
\hline Aggressive behavior & 101 & 10.00 & 45.00 & 20.2871 & 8.85589 \\
\hline Applicable N & 101 & & & & \\
\hline
\end{tabular}

To the results which are presented on graph, we got through summing and comparing the scores on the subscales for prosocial and aggressive behavior of children. It can be seen that most children manifest more prosocial than aggressive behavior. However, not too small percentage of children $(18 \%)$ manifested more aggressive behavior. Taking into account the fact that there is a danger of modeling aggression from peers, and then we have to consider this as a very important fact, which requires taking specific pedagogical measures, before the situation gets even worse. Aggressive children are often intrusive and dominant in the peer group, and known fact remains the existence of identification with the aggressor. Results of one study showed that social attitudes and behaviors that are built in the preschool period, maintained with slight modifications and changes (Hurlock, 1968, see at: Basic, Koller-Trbović, Žižak, 2005).
The aggressiveness of children is a disorder of behavior that often occurs in combination with some other disorders, and that requires professional treatment. "Since 1978, the first criminological research placed just child care providers in order to stifle the prevention of behavioral disorders in children, because of the sensitivity of children in this period of life, because of the importance of relationships that are then formed, and by the fact that some of such children, unfortunately, it will be encountered again in 10 or 15 years "(Basic, Koller-Trbović, Žižak, 2005, p.12). With this, the results gained even more severity, because it is not only about a problem that concerns the family or kindergarten, but a problem which every society should pay more attention to, of course, if it wants to promote socially acceptable patterns of behavior and values. 
The results of the average values in the subscales of prosocial and aggressive behavior indicate that the prosociality on average is more pronounced than aggression. It just goes in favor of validating our first subhypothesis, and that is that children on average manifest more prosocial than aggressive behavior. These results bring about the need to encourage the develop- ment of social skills and prosocial behavior, because it is the best way of weakening aggressive reaction preschoolers. This does not necessarily apply to children who have shown more aggressive behavior, but to all children. In such way we can act preventively to prevent the occurrence and development of aggressiveness, while also develop prosocial behavior.

Table 2: Descriptive statistics for prosocial and aggressive behavior in children by sex

\begin{tabular}{ccccc}
\hline Behavior & Sex & N & M & SD \\
\hline Prosocial behavior & Boys & 65 & 33.2923 & 7.96226 \\
\cline { 2 - 5 } & Girls & 36 & 37.6111 & 7.63929 \\
\hline Aggressive behavior & Boys & 65 & 21.9538 & 9.47930 \\
\cline { 2 - 5 } & Girls & 36 & 17.2778 & 6.72994 \\
\hline
\end{tabular}

Table 3: Significance of differences in the expression of prosocial and aggressive behavior of children by sex

\begin{tabular}{ccccc}
\hline Behavior & & \multicolumn{3}{c}{$\mathrm{t}$-test } \\
\cline { 2 - 5 } & & $\mathrm{t}$ & $\mathrm{df}$ & $\mathrm{p}$ \\
\hline Prosocial behavior & Equal variances assumed & -2.648 & 99 & $\mathbf{. 0 0 9}$ \\
\hline Aggressive behavior & Equal variances assumed & 2.615 & 99 & $\mathbf{. 0 1 0}$ \\
\hline
\end{tabular}

The second task of this study was to determine the possible differences in the expression of prosocial and aggressive behavior of children based on gender. Results of arithmetic means presented in "Table 2" show that there are differences in the manifestation of prosocial and aggressive behavior with regard to gender. To test whether these differences are statistically significant, we did t-test and got the following results. The value of t-test for prosocial behavior is $\mathrm{t}$ $=-2.648, \mathrm{p}<0.05$. From this we see that in addition to the obvious differences in arithmetic means, there is a statistically significant difference in the expression of prosocial behavior in relation to sex. For aggressive behavior value $t=2.615, \mathrm{p}<0.05$. Just as in the case with prosocial behavior, for aggressive behavior can be observed that there are significant differences with respect to gender. The results we obtained are in favor for many other researches which have also found that boys in the period pre-school are more aggressive than girls (Cummings, Ianotti \& Zahn-Waxler, 1989; Hyde, 1986, see Vasta and associates, 2004). As soon as boys are more aggres- sive, it would be logical that girls are more prosocial in their behavior, because those are behaviors that are located on opposite sides of the same continuum. Confirmation of that we received with the results of our research.

Gender differences in aggressiveness can be explained by biological and social factors. In biological factors we can mention the male sex hormones. According to the theory of socialization significance is given to parents and other forms environments, which differently influence boys and girls and have different expectations towards them. So the girls encourage prosocial behavior, while aggressiveness is disapproved.

The opposite is the case when it comes to boys, because they held some aggressive behavior more often considered socially permissible (Keenan \& Shaw, 1997; Maccoby, 1980; Schaffer, 2000- see at: Bryce Žganec, 2003). The results that we presented undoubtedly fully confirmed another sub-hypothesis of our research, and that is that boys are more aggressive and girls are more prosocial. 
Table 4. Descriptive statistics for prosocial and aggressive behavior of children in relation to the age of children

\begin{tabular}{ccccccc}
\hline \multirow{2}{*}{ Age of children } & $\mathrm{N}$ & $\mathrm{M}$ & SD & Min. & Max. \\
\cline { 2 - 7 } & 4 years & 43 & 29.7674 & 6.61469 & 20.00 & 50.00 \\
\cline { 2 - 7 } Prosocial behavior & 5 years & 31 & 38.5806 & 8.46866 & 20.00 & 50.00 \\
\cline { 2 - 7 } & 6 years & 27 & 38.5926 & 4.89316 & 18.00 & 43.00 \\
\cline { 2 - 7 } & Total & 101 & 34.8317 & 8.08216 & 18.00 & 50.00 \\
\hline \multirow{2}{*}{$\begin{array}{c}\text { Aggressive } \\
\text { behavior }\end{array}$} & 4 years & 43 & 21.7442 & 8.54983 & 11.00 & 44.00 \\
\cline { 2 - 6 } & 5 years & 31 & 19.2581 & 10.06965 & 10.00 & 45.00 \\
\cline { 2 - 6 } & 6 years & 27 & 19.1481 & 7.77424 & 10.00 & 37.00 \\
\hline
\end{tabular}

Based on the results presented in "Table 4" we notice that there are differences in the values of arithmetic means for prosocial and aggressive behavior between the groups. These differences are more pronounced in the prosocial behavior of children, especially between the four-year and five-year-group and between groups of four-year and six-year. Specific differences are apparent between the groups five year old and six year old in prosocial behavior.

A very similar situation is with aggressive behavior.
Thus, the difference in the values of arithmetic means is more noticeable between the group of the four-year and five-year olds and a four-year and six-year olds, while the differences between the groups five-year olds and six-year olds are almost invisible.

To determine whether the previously mentioned differences between groups statistically significant, we did an analysis of variance of manifested prosocial and aggressive behavior among groups of children of different ages.

Table 5. Analysis of variance firing prosocial and aggressive behavior in relation to the age of children

\begin{tabular}{rcccccc}
\hline & & The sum of squares & df & $\begin{array}{c}\text { Average } \\
\text { squares }\end{array}$ & F & p \\
& & & & & \\
\hline \multirow{2}{*}{$\begin{array}{c}\text { Prosocial } \\
\text { behavior }\end{array}$} & Between groups & 1920.397 & 2 & 960.199 & 20.404 & $\mathbf{. 0 0 0}$ \\
\cline { 2 - 7 } & Within groups & 4611.741 & 98 & 47.059 & & \\
\cline { 2 - 7 } & Total & 6532.139 & 100 & & & \\
\hline \multirow{2}{*}{$\begin{array}{c}\text { Aggressive } \\
\text { behavior }\end{array}$} & Between groups & 159.144 & 2 & 79.572 & 1.015 & .366 \\
\cline { 2 - 7 } & Within groups & 7683.529 & 98 & 78.403 & & \\
\cline { 2 - 7 } & Total & 7842.673 & 100 & & & \\
\hline
\end{tabular}

Analyzing of variance manifest prosocial and aggressive behavior of preschoolers, we found that there were statistically significant differences between groups in the manifestation of prosocial behavior, while there were no statistically significant differences between different age groups in the manifestation of aggressive behavior are present. 
Table 6: Significance of differences in the expression of prosocial behavior of four-year and five-year olds

\begin{tabular}{lcccc}
\hline & & \multicolumn{3}{c}{ t-test } \\
\cline { 3 - 5 } & & $\mathrm{t}$ & $\mathrm{df}$ & $\mathrm{p}$ \\
\hline $\begin{array}{l}\text { Prosocial } \\
\text { behavior }\end{array}$ & Equal variances assumed & -5.025 & 72 & $\mathbf{. 0 0 0}$ \\
\cline { 2 - 5 } & Equal variances not assumed & -4.829 & 54.643 & .000 \\
\hline
\end{tabular}

Table 7: Significance of differences in the expression of prosocial behavior of four-year and six-year olds

\begin{tabular}{ccccc}
\hline & & \multicolumn{3}{c}{$\mathrm{t}$-test } \\
\cline { 3 - 5 } & & $\mathrm{t}$ & $\mathrm{df}$ & $\mathrm{p}$ \\
\hline $\begin{array}{l}\text { Prosocial } \\
\text { behavior }\end{array}$ & Equal variances assumed & -5.975 & 68 & $\mathbf{. 0 0 0}$ \\
\cline { 2 - 5 } & Equal variances not assumed & -6.395 & 66.058 & .000 \\
\hline
\end{tabular}

In order to determine which, among age groups in terms of prosocial behavior has statistically significant differences, we used the "t-test". T-test values that we got showed that there are significant differences between group of four-year olds and group of five-year olds and a group of six-year olds (Tables 6 and 7), while statistically significant difference between the groups five-year olds and six year-olds group is not noticed, which could be observed from the average value of prosocial behavior of the mentioned age group.

Identified differences between group of four-year olds with a group of five-year olds and a group of six-year olds in the context of prosocial behavior are expected. The reason for that is that with time children adopt more social skills, because a larger number of situations give them the opportunity to acquire such social experience. Brajša, Zuzul and Keresteš (1991) point out that the expression of prosocial behavior begins very early in a child's life, from infancy. With increasing age, the frequency and complexity of prosocial behavior is increasing, so that such behavior is often seen in the older than in younger children. The lack of difference in prosociality of five-year olds and sixyear olds may be the result of changes in the cognitive development of children that occur in the fifth and sixth year of life. "At the end of the period in the development of preoperational thinking about the fifth or sixth year, the child begins to understand that there is a world apart from it, and so gradually its egocentrism disappears and the inability of taking someone else's point of view grows. Even then the child can see things from the perspective of the other person (Stojakovic, 2003, p. 96). This observation is important because basically prosocial behavior is empathy, which according to Suzić (2005) implies an understanding of the position, thinking, emotional state and actions of another person. Perhaps, this is precisely the reason for more pronounced prosociality behavioral of five-year olds and six-year olds compared to the four-year olds. Also, this may be the fact that explains the lack of significant difference in five-year olds and six-year olds prosociality, because of the disappearance of egocentrism in the opinion of the children began to appear just in the fifth and sixth year of life. As we previously mentioned, no statistically significant differences between different age groups of children in the context of aggressive behavior were identified. However, the results of the arithmetic mean value for each age group shows that there is still a tendency to decrease aggressiveness especially after the fourth year, and this tendency is slowing down and almost disappears between the fifth and sixth year of life. This tendency completely follows the movement of the development of prosocial behavior in the period after the fourth and fifth year, and stagnation in the development of prosociality between the fifth and sixth year of life. This confirmed that these are behaviors that are located on opposite sides of the same continuum, or that they are exclusive ways of behavior of children. The increase of one causes weakening of the second and vice versa. 
All results that were previously pointed out confirm a lesser extent of our third sub-hypotheses, because significant differences were detected only between certain groups within the means of prosocial behavior, whereas among all age groups in the context of aggressive behavior there were no observed statistically significant differences.

\section{CONCLUSIONS}

Based on the results we obtained in our study, we can conclude the following:

Preschool children manifest more prosocial than aggressive behavior, but also that it is not a small percentage of preschoolers by which aggressive behavior is dominating, which requires special attention and adequate pedagogical treatment in strengthening their social competence. This is confirmed by the first subhypotheses in our study.

Statistically significant differences in the manifestation of prosocial and aggressive behavior of pre-school children based on gender are determined, which is confirmation to the second sub-hypotheses of our research. Statistically significant differences in the manifestation of prosocial behavior of preschool children with regard to age, precisely to a group of four-year and five-year olds, and a group of five-year olds and six-year olds, while there were no statistically significant differences in the manifestation of prosociality between groups of five-year olds and six-year olds. Statistically significant differences in the expression of aggressive behavior in preschool children by age have not been established in our study. This is our third sub-hypotheses confirmed with a lesser extent, while it is largely discarded.

Of the three sub-hypotheses that we've set in our study, two were fully confirmed, while the third was confirmed only by a small part, while for the most part it was rejected. With this the main hypothesis of this study is largely confirmed, while only a smaller part is rejected.

\section{REFERENCES}

Bastašić, Z. (1990). Lutka ima i srce $i$ pamet. Zagreb: Školska knjiga.

Bašić, J., Kooler-Trbović, N., Žižak, A. (2005). Integralna metoda u radu sa predškolskom djecom i njihovim roditeljima. Zagreb: Alinea.

Bašić, J., Hudina, B., Koller-Trbović, N., Žižak, A. (2005). Integralna metoda (priručnik za odgajatelje i stručne suradnike u predškolskim ustanovama). Zagreb: Edukacijskorehabilitacijski fakultet Sveučilišta u Zagrebu i Alinea.

Bašić, J., Ferić, M., Kranželić, V. (2001). Od primarne prevencije do ranih intervencija. Zagreb: Edukacijsko-rehabilitacijski fakultet.

Bouillet, D., Uzelac, S. (2007). Osnove socijalne pedagogije. Zagreb: Školska knjiga.

Brajša-Žganec, A. (2003). Dijete i obitelj: Emocionalni i socijalni razvoj. Jastrebarsko: NAKLADA SLAP.

Brajša, A., Žužul, M., Keresteš, G. (1991). Odnos između agresivnog i prosocijalnog ponašanja. Rad izlagan na VIII danima psihologije u Zadru.

Eisenberg, N., Miller, P. (1987). The relationof empathy to prosocial and related behaviors. Psychological Bulletin, 101, 91-119.

Eisenberg,N., Mussen, P. (1989). The roots of prosocial behavior in children. Cambridge: Cambridge University Press.

Eron, L.D., Huesmann, L.R. (1984). The relation of the prosocial behavior to the development of aggression and psychopatology. Aggressive behavior, 14, 13-25.

Essau, C.A. (2003). Conduct and oppositional defiant disorders: Epidemiology, risk factors, and treatment. Hillsdale, NJ: Lawrence Erlbaum Associates.

Essau, C., Conradt, J. (2009). Agresivnost u djece i mladeži. Jastrebarsko: Naklada Slap.

Haug-Schnabel, G. (1997). Agresivnost u dječijem vrtiću. Zagreb: Educa.

Krnjajić, S. (2002). Podsticanje prosocijalnog ponašanja učenika, Socijalni odnosi i obrazovanje, str. 99-120. Beograd: IPI.

Krnjajić, S. (2002). Agresivno ponašanje učenika, Socijalni odnosi i obrazovanje, 209-230. Beograd: IPI.

Petermann, F., Petermann, U. (2010). Trening s agresivnom djecom. Zagreb: NAKLADA SLAP.

Stojaković, P. (2003). Psihologija za nastavnike. Banja Luka: Prelom.

Suzić, N. (2005). Pedagogija za XXI vijek. Banja Luka: TT-Centar.

Vasta, R., Haith, M., Miller, S. (2004). Dječja psihologija. Jastrebarsko: Naklada Slap.

Wenar, C. (2003). Razvojna psihopatologija i psihijatrija. Jastrebarsko: Naklada Slap.

Vlahović-Štetić, V. (1994). Priručnik za skalu za procjenu agresivnog i prosocijalnog ponašanja kod djece. Jastrebarsko: Naklada Slap. 